\title{
The conservation benefit of mowing vs grazing for management ofspecies-rich grasslands: a multi-site, multi-year field experiment
}

\author{
Malin Tälle, Håkan Fogelfors, Lars Westerberg and Per Milberg
}

\section{Linköping University Post Print}

\section{Tweet}

N.B.: When citing this work, cite the original article.

Original Publication:

Malin Tälle, Håkan Fogelfors, Lars Westerberg and Per Milberg, The conservation benefit of mowing vs grazing for management ofspecies-rich grasslands: a multi-site, multi-year field experiment, 2015, Nordic Journal of Botany, (33), 6, 761-768.

http://dx.doi.org/10.1111/njb.00966

Copyright: Wiley: 12 months

http://eu.wiley.com/WileyCDA/

Postprint available at: Linköping University Electronic Press

http://urn.kb.se/resolve?urn=urn:nbn:se:liu:diva-123378 
The conservation benefit of mowing vs. grazing for management of species-rich grasslands: a multi-site, multiyear field experiment

Malin Tälle, Håkan Fogelfors, Lars Westerberg, Per Milberg

Milberg, P. (corresponding author per.milberg@liu.se), Tälle, M.

(malin.talle@liu.se), Westerberg, L. (lars.westerberg@liu.se): IFM

Biology, Conservation Ecology Group, Linköping University, SE-581 83 Linköping, Sweden

Fogelfors, H. (hakan.fogelfors@slu.se): Department of Crop Production Ecology, Swedish University of Agricultural Sciences, Box 7043, SE75007 Uppsala, Sweden 


\section{Abstract}

Species-rich semi-natural grasslands in Europe are becoming more fragmented and many species that depend on this habitat type are rare and threatened today. Management methods like mowing and grazing are needed to preserve remaining grasslands. Since management is costly it is important to use the most cost effective as well as the most beneficial management method, but few previous studies have compared mowing and grazing. We investigated the effect of mowing and grazing on grassland vegetation using data from 11 long-term field trials situated in southern Sweden. We calculated the change in the odds of finding species belonging to three different groups of indicators at the start of the treatment and after 8 and 14 years. The indicator groups used were indicators of good management, excess nitrogen and poor management. The results revealed an increase in the odds of finding indicators of good management in mowed plots and an increase in finding indicators of excess nitrogen in grazed plots. The odds of finding indicators of poor management remained unchanged. Results from sub-analysis of the grazing intensity showed a more negative effect from grazing with low grazing intensity than normal/high grazing intensity. Therefore, mowing is the best long-term management method for semi-natural grasslands in Sweden and grazing using a low grazing intensity should be avoided. 
Keywords:

Indicators, Meta-analysis, Odds ratio, Semi-natural grassland, Sweden

Abbreviations

Log OR $=$ log odds ratio

Nomenclature

Karlsson (1998) 


\section{Introduction}

Nutrient-poor, semi-natural grasslands are one of the most species-rich habitats in the agricultural landscape of Europe (Poschlod et al. 2009) and this habitat type can harbour a high diversity of plant and animal species (Kull and Zobel 1991, D’Aniello et al. 2011, Wilson et al. 2012). Furthermore, semi-natural grasslands provide ecosystem services such as pollination, carbon sequestration and erosion regulation (Öckinger and Smith 2006, Bazzoffi 2008, De Deyn et al. 2011). Therefore, semi-natural grasslands are widely recognized to have a high conservation value. Traditionally, semi-natural grasslands were used as pastures for grazing or as hay meadows, the latter being vital for the availability of winter fodder (Pedersen and Widergren 2011). Over the last century the use of inorganic fertilizers to improve yields has increased, but to the disadvantage to many species (Ceulemans et al. 2013). In addition, management of many semi-natural grasslands has ceased. This results in an increase of tall grasses and forbs in grasslands, which in turn reduces biodiversity (Peco et al. 2012). Furthermore, cessation of management has resulted in afforestation through tree planting or natural succession (Milberg 1995, Hansson and Fogelfors 2001). These changes in management and land use have had a negative effect on the diversity of semi-natural grasslands (Firbank 2005) and many of the species that 
thrive in this habitat are today rare and threatened (The IUCN Red List of Threatened Species 2014).

Conservation of species relying on the remaining semi-natural grasslands is dependent on the management (e.g. mowing and grazing) that keep this habitat type open (Valkó et al. 2012). However, the management of semi-natural grasslands is becoming increasingly more difficult as it is costly to manage areas by mowing (Schreiber et al. 2009, Török et al. 2011) and difficult to ensure livestock for conservation grazing (Kumm 2003). Therefore, it is important to ensure that the "best" management option is used when managing semi-natural grasslands to make the best use of the limited resources available for management. Consequently it is important to evaluate the benefits of the two most widely used management options (i.e. mowing and grazing). However, surprisingly few studies comparing the effect of mowing and grazing have been published and the results are often contradicting, with results in favour of mowing (e.g. Wahlman and Milberg 2002), grazing (e.g. de Cauwer and Reheul 2009), or both (e.g. Kahmen et al. 2002). Furthermore, few studies consider the effect of the grazing intensity when comparing mowing and grazing, Studies often compare two grasslands located in the same area under different management (e.g. Rūsinga et al. 2013, Catorci et al. 2014) or survey a larger number of sites managed by 
either mowing or grazing (e.g. Schläpfer et al. 1998, Herbst et al. 2013). There are a few studies that provide more unequivocal evidence through field trials, but most of these are unreplicated (e.g. Kahmen et al. 2002) and few involve a replicated field trial over more than a few seasons (e.g. Louault et al. 2005). As differences between management using mowing or grazing most likely are small to moderate, no quick divergence of treatments can be expected (Milberg et al. 2014), which is why data from a series of experiments involving several sites over many years are particularly valuable (Steen 1976, Fogelfors 1982, Hansson 1991, Wahlman and Milberg 2002, Milberg et al. 2014).

“Evidence-based conservation” involves the assembly of complex information from various places and the interpretation of the "best available evidence” (Pullin and Knight 2004, Sutherland et al. 2004). The purpose is to provide managers with information to support the decisionmaking process when choosing suitable management practices.

The aim of the present study was to compare the traditional management methods of mowing and grazing, to determine the best management practice for maintaining the desired composition of seminatural grassland vegetation. By maintaining species typical of unfertilized and traditionally managed grasslands (Ekstam and Forshed 1996) this goal can be achieved in the long term. We used data from 11 
field trials in southern Sweden and groups of indicators to describe the vegetation composition. These included indicator species of good management (for species richness); excess nitrogen; and poor management. To contrast mowed and grazed plots we used meta-analysis to calculate the odds of finding these indicators at three time points. Furthermore, we compared the effect of different grazing intensities. The best management practice is the one in which odds ratios stay the same or change in a desirable direction (i.e. an increase in indicators of good management and/or a decrease in indicators of excess nitrogen and poor management).

\section{Methods}

\section{Study sites}

The long-term experiment was established in the 1970's, in 11 experimental sites at nine locations in southern Sweden. Two of the locations, Ekenäs and Tagel, had two experimental sites each (Fig. 1). The mean annual precipitation for southern Sweden is 500-1000 mm and the mean annual temperature is around $6{ }^{\circ} \mathrm{C}$ (Alexandersson et al. 1991). The growing period is 180-220 days (Sjörs 1999). Before the start of the experiment most sites were managed using grazing. However, two of the sites (Dämkärr and Österplana) had been abandoned for a few years and 
one site (Gränö) was mowed. Furthermore, two of the sites (Gränö and Tagel/Former field) were fertilized prior to the start of the experiment (Table 1, Hansson 1991). The sites differed in vegetation type and productivity. The majority of sites were of mesic meadow type (Table 1), with a medium productivity (Hansson 1991). Furthermore, the sites can be classified as semi-natural dry grasslands (6210), hay meadows in submontane zones (6510), Fennoscandian wooded pastures (9070) or wet meadows (Molinion caeruleae) (6410), according to the Council Directive 92/43/EEC on the Conservation of natural habitats and of wild fauna and flora (Swedish Environmental Protection Agency 2011). Information on the meadow types and examples of characteristic species can be found in Table 2. The soil type, nutrient conditions and the grazer type and grazing intensity varied between sites (Table 1, Hansson 1991).

\section{Experimental design}

The experiment was set up with the aim to assess vegetation changes as a result of the introduction of several management methods. For the present study we evaluated two of the management methods: mowing and grazing. The management methods were applied to $5 \times 20 \mathrm{~m}$ treatment plots. Treatment plots were set within a randomized block design with two replicates. All plots except the grazed ones were fenced. The mowing plots were mowed in late July or early August, using a scythe or sickle 
bar mower. The majority of grazing plots were grazed using cattle at varying grazing intensity. However, in a few cases or for some years sheep or horses were used.

\section{Vegetation sampling}

Fieldwork was conducted in July, before mowing took place. Different sampling methods were used for different sites and years. For six trials the whole treatment plot was sampled for the initial surveys. For two surveys (Bräcke, Ekenäs/Moist) the treatment plots were divided into two subplots that were surveyed individually. For three sites either three (Bråbo) or five (Andersby, Österplana) $1 \mathrm{~m}^{2}$ per treatment plot were surveyed. In the 1980's five $1 \mathrm{~m}^{2}$ fixed subplots were used for all trials except one (Bräcke) where six $1 \mathrm{~m}^{2}$ fixed subplots were used. For the surveys, the coverage of vascular plant species was recorded. In the majority of plots the cover percentage was surveyed, while the HultSernander-duRietz scale was used in a few surveys (Steen 1976; Fogelfors 1982; Hansson 1991). Regardless of the survey method, presence-absence data was used in the present analysis. If presenceabsence data from subplots were unavailable, data from the whole treatment plot was used instead.

For the present study we used data from fieldwork conducted in 1973 (nine trials; Steen 1976), 1975 (two trials; Steen 1976), 1980 (seven 
trials; Fogelfors 1982), 1986 (ten trials; Hansson 1991), and 1987 (one trial; Hansson 1991).

\section{Classification of plant species}

We used existing indicator systems classifying grassland species as indicators to simplify the data. This enabled the comparison of data from different sites and years and gathered using different methods. When using evidence-based conservation to deal with the management of plant communities it is important to find biologically relevant indicators that can be used in meta-analyses (Milberg 2014, Milberg et al. 2014, Tälle et al. 2014). Furthermore, there is often an overlap between the species lists of different indicator systems. Despite this the choice of indicator system might influence the results (Milberg et al. 2014). Therefore we included two different indicator systems. We specifically choose two welldocumented indicator systems targeting species-rich semi-natural grasslands in southern Sweden, as indicator systems work best in their area of geographic origin (e.g. Jansson et al. 2009), and when used for their intended purpose. The species were recorded into the following three groups that we considered to be ecologically relevant when managing for conservation of species-rich semi-natural grasslands: (1) indicators for good management for species richness, (2) indicators of 
excess nitrogen, and (3) indicators of poor management (Supplementary material Appendix 1, Table A1).

The indicator system of Bertilsson \& Paltto (2003) is a regional indicator system developed for the province of Västergötland (Österplana is situated in this province, Fig. 1) with the goal of evaluating the grazing management status in grasslands. Ekstam \& Forshed (1992) is a national indicator system widely used by practitioners. This system classifies species according to a nitrogen availability gradient (three classes) and considers the rate at which a species is lost during secondary succession from grassland to forest (four classes). We classified species as indicators of good management for species richness if they decrease in early succession stages (classes A and B) and grow in sites poor in nitrogen (N1). Indicator species of excess nitrogen were species of all successional phases (classes A-D) and grow in nitrogen rich sites (N3). Indicator species of poor management does not decrease until late successional stages (classes C and D) and grow in nutrient-poor sites or sites with moderate levels of nitrogen (classes N1 and N2).

\section{Statistical analyses}

We analysed the data using odds ratio, as a way of overcoming the differences in the survey method and the differing number of subplots between different sites and years. This analysis method compared the 
odds of a species recorded being an indicator between the two treatments at the start and end of the trial.

For each group of indicators we first calculated the total number of indicators and non-indicators (i.e. all other species) per subplot, or per treatment plot if subplots were not used. We then summed the number of indicators and non-indicators per treatment plot (if subplots were surveyed). This measure reflects the frequency of the indicator species and non-indicator species in each treatment plot.

To compare the mowing treatment with the grazing treatment a random effects meta-analysis was performed using Comprehensive Metaanalysis version 2 (Biostat, Inc. 2006; www.meta-analysis.com).

The effect sizes were measured as log odds ratio (OR):

$$
\log \mathrm{OR}=\log [(\mathrm{A} \times \mathrm{D} /(\mathrm{B} \times \mathrm{C})]
$$

where, $\mathrm{A}=$ frequency of indicators in the mowing treatment; $\mathrm{B}=$ frequency of non-indicators in the mowing treatment; $\mathrm{C}$ = frequency of indicators in the grazing treatment; $\mathrm{D}=$ frequency of non-indicators in the grazing treatment. As each trial contained two blocks, each trial contributed two entries into the meta-analysis. Meta-analysis was performed for all data. We also performed a sub-analysis where trials were grouped according to the grazing intensity in the year of the final 
assessment (12, 14 or 15 years). The latter was given as qualitative statements about management stated in the report written (Hansson 1991) that was authored by the field worker (M. Hansson, $\mathrm{PhD}$ ). Two groups were used: low grazing intensity ( $\mathrm{N}=5$ trials) and normal/high grazing intensity ( $\mathrm{N}=6$ trials). Normal and high grazing intensity was grouped together as only one trial used high grazing intensity.

We considered that the conservation value was favored if the odds of finding indicators of good management for species richness remained the same or increased while the odds of finding indicators of excess nitrogen and poor management remained the same or decreased.

\section{Results}

In total, the data considered in the present study involved 290 species of plants. The indicator systems for good management for species richness made up 17 and 18\%, indicators of excess nitrogen made up 8 and 11\% and indicators of poor management made up 2 and $20 \%$ of the 290 species (scores refer to the indicator system of Bertilsson \& Paltto and Ekstam \& Forshed respectively) (Supplementary material Appendix 1, Table A1)

The odds of finding indicators of good management for species richness were higher in mowed plots compared with grazed plots (log OR 
$>0,21$ ) (Fig. 2a). The odds of finding indicators of excess nitrogen increased over time in grazed plots $(\log \mathrm{OR}<-0,1)$ (Fig. 2b). No clear trend could be seen among the indicators for poor management $(\log \mathrm{OR}=$ $-0,004$ or $-0,06$ ) (Fig. 2c). As expected the trends varied somewhat among indicator systems.

When grouping the trials according to the grazing intensity (either low or normal/high) the odds of finding indicators of good management for species richness was highest in mowed plots, when comparing mowing and low grazing intensity (log OR $>0,4)$ (Fig. 3a). When comparing the odds of finding indicators of excess nitrogen the results were more similar between grazing intensities (log OR between -0,016 and -0,197) (Fig. 3b). The results were less clear for the odds of finding indicators of poor management, with no differences between the grazing intensities for one indicator system ( $\log \mathrm{OR}=-0,066$ or $-0,052)$ (Bertilsson \& Paltto). For the Ekstam \& Forshed indicator system the odds of finding indicators of poor management was highest in mowed plots when comparing mowing and normal/high grazing intensity (log $\mathrm{OR}=0,211$ ), while the odds were higher in grazed plots when comparing mowing with low grazing intensity (log $\mathrm{OR}=-0,254)$ (Fig. 3c). 


\section{Discussion}

Our results, using data from 11 replicated field trials spanning 15 years, revealed a positive effect of mowing on indicators of good management for species richness and excess nitrogen over time and an unchanged effect of management on indicators of lack of management (Fig. 2). These results suggest that mowing is a better long-term management method compared with grazing for semi-natural grasslands of Sweden, which is in agreement with studies analyzing part of the same data (Hansson and Fogelfors 2000, Wahlman and Milberg 2002). Other studies from e.g. Switzerland and Italy have also found a more positive effect of mowing compared with grazing on e.g. plant species richness (e.g. Peter et al. 2009, Catorci et al. 2014). However, there are also examples of studies finding a more positive effect of grazing (e.g. Schläpfer et al. 1998). A recurring problem involving experiments with grazers is the difficulty to control the "dose of grazing" (see further below); and in the present study, there is indication that grazing was insufficient for conservation purposes in several of the trials (Hansson 1991). If including only trials that had "normal” or "high" grazing intensity in its final year, the difference between odds ratios became less clear. 
The mechanisms involved in the difference between mowing and grazing are not completely clear. However, studies have shown that mowing and grazing can have different effects on plant functional traits and the functional diversity of semi-natural grasslands (de Bello et al. 2006, Catorci et al. 2011), resulting in different plant species being favored by different management practices. For example, mowing increases the occurrence of plant species of high palatability, while grazing increases the occurrence of short-lived species (which can more easily colonize disturbances caused by grazers) (Bullock et al. 2001, Catorci et al. 2011). This might also be the explanation to the more negative effect of grazing found in this study, as Fisher and Wipf (2002) suggested that the long-term negative effects of grazing compared with mowing found in a study performed in Switzerland may be caused by a sensitivity of plant species to trampling and selective grazing. However, other studies have found that the heterogeneity created by trampling and selective grazing can have a positive effect on the biodiversity of grasslands (Palmer 1992, Dufour et al. 2006, Török et al. 2014). Furthermore, our results indicate that grazing is more related to higher amounts of nutrients (Fig. 2b) which explain why mowing is better at sustaining species richness. Generally, a sparsity of nutrients is pivotal to maintain the species richness and composition of semi-natural grasslands. While both mowing and grazing depletes grasslands of nutrients, grazing 
facilitates recycling of nutrients through dung and urine from grazers (Detling 1998) and increases the turnover of nutrients (Lepš et al. 1995). Thus, it seems plausible that the nutrient removal facilitated by mowing is a reason for the more positive effect of mowing compared with grazing on the species richness.

Different grazing intensities had different effects on the vegetation. Normal/high grazing intensity maintained the odds of finding all indicators throughout the trial (Fig. 3a-c). As this means indicators of excess nitrogen and lack of management did not increase (in relative terms), normal/high grazing intensity had a positive effect on the vegetation. The intensity of grazing is affected by the number of grazers, grazer type and the size of a pasture, but can also be affected by plant species traits like palatability (Hassani et al. 2008). Furthermore, the distribution of vegetation and water and the pasture terrain can affect the grazing intensity, along with the feedback between grazing and plant quality (as grazing may improve the nutrient and crude protein content of available forage) (Adler et al. 2001). There are few studies that have evaluated the effect of grazing intensity on semi-natural grassland vegetation. Stewart and Pullin (2008) suggested that intermediate grazing intensity may be most appropriate for conservation of mesotrophic pastures, though the evidence base was poor. Studies in arid 
environments revealed a negative effect of high grazing intensity on the vegetation (e.g. Zhao et al. 2007). Similar effects can be expected in semi-natural grasslands but as our analysis only contained one trial with high grazing intensity (which had to be grouped with trials with normal grazing intensity) no conclusions can be drawn on the effect of high grazing intensity in this case. Low grazing intensity had a more negative effect on indicators of good management for species richness and some indicators of poor management increased with low grazing intensity (Fig 3c). This is probably an effect of the development of a more closed canopy, due to an increase in tall plant species (Golodets et al. 2010). This reduces the light availability, which in turn causes a decrease in plant species richness (Einarsson \& Milberg 1999).

Our results suggest that annual mowing should be the preferred conservation management method of semi-natural grasslands in Sweden. The somewhat contradictory reports from elsewhere in Europe (Schläpfer et al. 1998, Peter et al. 2009, Catorci et al. 2014) suggest more caution about generalising these conclusions too widely. Nevertheless, similar management effects should be expected in European grasslands similar to the ones investigated. Furthermore, the results are valuable when comparing management effects across different climatic contexts and pastoral landscapes. In addition, there is a general lack of studies 
comparing effects of management practices, which make the present results an important addition to the general knowledge base regarding management effects, potentially making this study important to future meta-analyses analysing management effects on larger scales.

Furthermore, our results highlight the importance of avoiding low grazing intensities. It is important to note that what constitutes as low grazing intensity may differ e.g. depending on the productivity of a grassland. In addition, it is important to note that the vegetation of semi-natural grasslands can be affected by both management and the environmental site conditions as well as the intensity of mowing or grazing (Klimek et al. 2007, Catorci et al. 2012, Milberg 2014), and the type of grazer (Sebastià et al. 2008). Therefore, all these factors need to be considered when interpreting the present results and when determining a suitable management practice. For instance, wet semi-natural grasslands are usually more productive and might therefore not benefit from mowing only once a year (Schrautzer et al. 1996). The previous management must also be considered when determining the most suitable management method of a grassland, as a shift in management method may affect the flora (Jantunen 2003). In the present study most sites involved cases with a shift from grazing to mowing at the onset of the trials; however, several of the sites had a history of mowing somewhat further back in time which make our data unsuitable to assess this matter. 
There are subsidies available for farmers in the EU, e.g. to support the management of semi-natural grasslands. As these subsidies represent a substantial societal investment, it is important that the funds are used in the best possible way, with more support provided to the best available management option. In Sweden, farmers currently receive higher subsidies for management using mowing compared with grazing (in 2015: 4500 SEK/ha compared to 2800 SEK/ha, when the grassland contains high nature values (i.e. high species richness or a unique flora) (Swedish Board of Agriculture 2015)). Based on our results this seems justified, as mowing had a more positive effect on the flora compared with grazing and therefore is the best management option for seminatural grasslands of Sweden, and possibly the northern part of Europe.

Using odds ratios makes it possible to give meaning to the estimated effect sizes (Rita and Komonen 2008). In this case the maximum change in log odds ratio was around 0.4 , which corresponds to $d=0.22$ i.e. the difference between mowing and grazing is 0.22 SD units. This is considered a relatively small effect size (Cohen 1992) and the results must be interpreted with this in mind. However, as few studies have used odds ratios to convert vegetation data, more studies are needed to put the current effect sizes into perspective. Milberg et al. (2014) studied the effect of spring burning on grassland vegetation compared 
with grazing and mowing, and recorded $d=0.28$; while Tälle et al. (2014) compared different methods for mowing, and failed to detect an effect $(d=0.1)$.

As we had expected the choice of indicator system influenced the results. Despite an overlap in species composition, the effect sizes varied between indicator systems. Milberg et al. (2014) recommended the use of management-specific indicator systems, as compared to e.g. species lists of typical grassland species. However, in the present case this still resulted in differences between systems. In future studies it is therefore important to carefully consider the choice of indicator system. The best results are achieved when using indicator systems developed for a specific area (Jansson et al. 2009), e.g. targeting species-rich semi-natural grasslands. This makes it more difficult to compare effect sizes from different contexts e.g. when comparing experiments conducted in parts of Europe with very different flora and indicator species systems. Nevertheless, general conclusions may be drawn from the trends in the effect size. In addition, the sampling methodology may affect the precision of the effect size estimates (Milberg et al. 2014) and we caution against merging data generated using vastly different methodologies or generated by several different fieldworkers as the skill in identifying plant species may differ. 


\section{Conclusions}

The results from this study revealed that mowing had a more positive effect on indicators of good management for species richness, while grazing increased the odds of finding indicators of excess nitrogen. Therefore, the recommended long-term management alternative to preserve the conservation status in the species-rich semi-natural grasslands of Sweden is mowing. Furthermore, the grazing intensity has an effect on the vegetation and a low grazing intensity should be avoided.

\section{Acknowledgements}

We thank all those involved in initiating, maintaining and monitoring the long-term field trials analysed here. The Swedish Environmental Protection Agency initially funded these trials. Financial support for our study was provided by the Swedish Board of Agriculture and Stiftelsen Oscar och Lili Lamms minne.

\section{References}

Adler, P.B., Raff, D.A. and Lauenroth, W.K. 2001. The effect of grazing on the spatial heterogeneity of vegetation. - Oecologica. 128: 465-479.

Alexandersson, H., Karlström, C. and Larsson-McLann, S. 1991.

Temperaturen och nederbörden i Sverige 1961-1990. Referensnormaler. - 
Sveriges Meteorologiska och Hydrologiska Institut, SMHI Meteorologi No. 81.87 pp. In Swedish.

Bazzoffi, P. 2009. Soil erosion tolerance and water runoff control:

minimum environmental standards. - Reg. Environ. Change 9: 169-179.

Bertilsson, A. and Paltto, H. 2003. Hagar i Skaraborg år 2001: en återinventering med miljöövervakningssyfte. - County Administration Board of Västra Götaland. 2003:15.

$<\underline{\text { http://www.lansstyrelsen.se/vastragotaland/SiteCollectionDocuments/Sv }}$ /publikationer/2003/rapport200315.pdf>, accessed 7 May 2015. In Swedish.

Biostat, Inc. 2006. Comprehensive Meta-analysis version 2. < $\underline{\text { www.meta- }}$ $\underline{\text { analysis.com }>}$

Bullock, J.M., Franklin, J., Stevenson, M.J., Silvertown, J., Coulson, S.J., Gregory, S.J. and Tofts, R. 2001. A plant trait analysis of responses to grazing in a long-term experiment. - J. Appl. Ecol. 38: 253-267.

Catorci, A., Cesaretti, S., Malatesta, L. and Tardella, F.M. 2014. Effects of grazing vs mowing on the functional diversity of sub-Mediterranean productive grasslands. - Appl. Veg. Sci. 17: 658-669. 
Catorci, A., Ottaviani, G., Ballelli, S. and Cesaretti, S. 2011. Funtional differentiation of central Apennine grasslands under mowing and grazing disturbance regimes. - Pol. J. Ecol. 59: 115-128.

Catorci, A., Ottaviani, G., Vitasović Kosić, I. and Cesaretti, S. 2012. Effect of spatial and temporal patterns of stress and disturbance intensities in a sub-Mediterranean grassland. - Plant Biosyst. 146: 652367.

Ceulemans, T., Merckx, R., Hens, M., and Honnay, O. 2013. Plant species loss from European semi-natural grasslands following nutrient enrichment - is it nitrogen or is it phosphorus? - Global Ecol. Biogeogr. 22: 73-82.

Cohen, J. (1992) A power primer. - Psychol. Bull. 112: 155-159.

D’Aniello, B., Stanislao, I., Bonelli, S. and Balletto, E. 2011. Haying and grazing effects on the butterfly communities of two Mediterranean-area grasslands. - Biodiv. Conserv. 20: 1731-1744.

Davies, C.E., Moss, D. and Hill, M.O. 2004. EUNIS habitat classification revised 2004. http://www.eea.europa.eu/themes/biodiversity/eunis/eunis-habitatclassification/documentation/eunis-2004-report.pdf, accessed 27 August 2015. 
de Bello, F., Lepš, J and Sebastià, M.-T. 2006. Variations in species and functional plant diversity along climatic and grazing gradients. Ecography. 29: 801-810.

de Cauwer, B. and Reheul, D. 2009. Impact of land use on vegetation composition, diversity and potentially invasive, nitrophilous clonal species in a wetland region in Flanders. - Agron. Sustain. Dev. 29: 277285.

De Deyn, G.B., Shiel, R.S., Ostle, N.J., McNamara, N.P., Oakley, S., Young, I., Freeman, C., Fenner, N., Quirk, H. and Bardgett, R.D. 2011. Additional carbon sequestration benefits of grassland diversity restoration. - J. Appl. Ecol. 48: 600-608.

Detling, J.K. 1998. Mammalian herbivores: Ecosystem-level effects in two grassland national parks. - Wildlife Soc. B. 26: 438-448.

Dufour, A., Gadallah, F., Wagner, H.H., Guisan, A. \& Buttler, A. 2006. Plant species richness and environmental heterogeneity in a mountain landscape: effects of variability and spatial configuration. - Ecography 29: 573-584.

Einarsson, A. and Milberg, P. 1999. Species richness and distribution in relation to light in wooded meadows and pastures in southern Sweden. Ann. Bot. Fenn. 36: 99-107. 
Ekstam, U. and Forshed, N. 1992. Om hävden upphör; kärlväxter som indikatorarter i ängs- och hagmarker. - Naturvårdsverket Förlag, in Swedish.

Ekstam, U. and Forshed, N. 1996. Äldre fodermarker: betydelsen av hävdregimen i det förgångna, målstyrning, mätning och uppföljning. Naturvårdverket Förlag.

Firbank, L.G. 2005. Striking a new balance between agricultural production and biodiversity. - Ann. Appl. Biol. 146: 163-175.

Fischer, M., and Wipf, S. 2002. Effect of low-intensity grazing on the species-rich vegetation of traditionally mown subalpine meadows. - Biol. Conserv. 104: 1-11.

Fogelfors, H. 1982. Det marginella odlingslandskapets öppethållande. Del II. Resultat och utvärdering av långvariga försök med olika skötselmetoder. - Swedish University of Agricultural Sciences. Department of Ecology and Environmental Research. Report No. 11. In Swedish.

Golodets, C., Kigel, J. and Sternberg, M. 2010. Recovery of plant species composition and ecosystem function after cessation of grazing in a Mediterranean grassland. - Plant Soil. 329: 365-378. 
Hansson, M. 1991. Management of semi-natural grassland. Results of a fifteen-year- old field experiment in south and central Sweden. - Swedish University of Agricultural Sciences, Uppsala. Department of Ecology and Environmental Research. Report No. 45. In Swedish with English summary.

Hansson, M. and Fogelfors, H. 2000. Management of semi-natural grassland; results from a 15-year old experiment in southern Sweden. - J. Veg. Sci. 11: 31-38.

Hassani, N., Asghari, H.R. and Nurberdief, M. 2008. Impacts of overgrazing in a long term traditional grazing ecosystem on vegetation around watering points in a semi-arid rangeland of north-eastern Iran. Pak. J. Biol. Sci. 11: 1733-1737.

Herbst, C., Wäschke, N., Barto E.K., Arnold, S., Geuß, D., Halboth, I., Reschke, S., Sänger, J., Meiners, T. and Obermaier, E. 2013. Land use intensification in grasslands: higher trophic levels are more negatively affected than lower trophic levels. - Entomol. Exp. Appl. 147: 269-281.

Jansson, N., Bergman, K.-O., Jonsell, M., and Milberg, P. 2009. An indicator system for identification of sites of high conservation value for saproxylic oak (Quercus spp.) beetles in southern Sweden. - J. Insect Conserv. 13: 399-412. 
Jantunen, J. 2003. Vegetation changes in a semi-natural grassland during mowing and grazing periods. - Ann. Bot. Fenn. 40: 255-263.

Karlsson, T. 1998. Förteckning över svenska kärlväxter. [The vascular plants of Sweden - a checklist]. - Svensk Bot. Tidskr. 91: 241-560. In Swedish.

Kahmen, S., Poschlod, P. and Schreiber, K.-F. 2002. Conservation management of calcareous grasslands. Changes in plant species composition and response of functional traits during 25 years. - Biol. Conserv. 104: 319-328.

Klimek, S., Richter gen. Kemmermann, A., Hofmann, M. and Isselstein, J. 2007. Plant species richness and composition in managed grasslands: the relative importance of field management and environmental factors. Biol. Conserv. 134: 559-570.

Kull, K. and Zobel, M. 1991. High species richness in an Estonian wooded meadow. - J. Veg. Sci. 2: 711-714.

Kumm, K.-I. 2003. Sustainable management of Swedish seminatural pastures with high species diversity. - J. Nat. Conserv. 11: 117-125. 
Lepš, J., Michálek, J., Kulíšek, P. and Uhlík, P. 1995. Use of paired plots and multivariate analysis for the determination of goat grazing preference. - J. Veg. Sci. 6: 37-42.

Louault, F., Pillar, V.D., Aufrère, J., Garnier, E. and Soussana, J.-F. 2005. Plant traits and functional types in response to reduced disturbance in a semi-natural grassland. - J. Veg. Sci. 16: 151-160.

Milberg, P. 1995. Seed bank after eighteen years of succession from grassland to forest. - Oikos 72: 3-13.

Milberg, P. 2014. Evidence-based vegetation management: prospects and challenges. - Appl. Veg. Sci. 17: 604-608.

Milberg, P., Akoto, B., Bergman, K.-O., Fogelfors, H., Paltto, H. and Tälle, M. 2014. Is spring burning a viable management tool for seminatural grasslands? - Appl. Veg. Sci. 17: 429-441.

Öckinger, E. and Smith, H.G. 2007. Semi-natural grasslands as population sources for pollinating insects in agricultural landscapes. - J. Appl. Ecol. 44: 50-59.

Palmer, M.W. 1992. The coexistence of species in fractal landscapes. Am. Nat. 139: 375-397. 
Peco, B., Carmona, C.P., de Pablos, I. and Azcárate, F.M. 2012. Effects of grazing abandonment and taxonomic diversity of Mediterranean grasslands. - Agr. Ecosyst. Environ. 152: 27-32.

Pedersen, E.A. and Widgren, M. 2011. Agriculture in Sweden 800 BC AD 1000. - In: Myrdal, J. and Morell, M (eds.), The Agrarian History of Sweden from 4000 BC to AD 2000. Nordic Academic Press, pp. 46-71.

Peter, M., Gigon, A., Edwards, P.J. and Lüscher, A. 2009. Changes over three decades in the floristic composition of nutrient-poor grasslands in the Swiss Alps. - Biodivers. Conserv. 18: 547-567.

Poschlod, P., Baumann, A. and Karlik, P. 2009. Origin and development of grasslands in central Europe. - In: Veen, P., Jeffersson, R., de Smidt, J., and van der Straaten, J. (eds.), Grasslands in Europe - of high nature value. KNNV Publishing, pp. 12-25.

Pullin, A.S. and Knight, T.M. 2004. Support for decision making in conservation practice: an evidence-based approach. - J. Nat. Conserv. 11: 83-90.

Rita, H. and Komonen, A. 2008. Odds ratio: an ecologically sound tool to compare proportions. Ann. Zool. Fenn. 45: 66-72. 
Rūsiņa, S., Pušpure, I. and Gustiņa, L. 2013. Diversity patterns in transitional grassland areas in floodplain landscapes with different heterogeneity. - Tuexenia 33: 347-369.

Schläpfer, M., Zoller, H. and Körner, C. 1998. Influences of mowing and grazing on plant species composition in calcareous grassland. - Bot. Helv. 108: 57-67.

Schrautzer, J., Asshoff, M. and Müller, F. 1996. Restoration strategies for wet grasslands in Northern Germany. - Ecol. Eng. 7: 255-278.

Schreiber, K.-F., Brauckmann, H.-J., Broll, G., Krebs. S. and Poschlod, P. 2009. Artenreiches Grünland in der Kulturlandschaft. 35 Jahre Offenhaltungsversuche Baden-Württemberg. - Verlag Regionalkultur, in German.

Sebastià, M.-T., de Bello, F., Puig, L. and Taull, M. 2008. Grazing as a factor structuring grasslands of the Pyrenees. - Appl. Veg. Sci. 11:215222.

Sjörs. H. 1999. The background: geology, climate and zonation. - Acta Phytogeogr. Suecica. 84: 5-14.

Steen, E. 1976. Det marginella odlingslandskapets öppethållande. Dokumentation i långvariga försök med olika skötselmetoder. - 
Lantbrukshögskolan, Avdelningen för ekologisk miljövård, Uppsala. In Swedish.

Stewart, G.B. and Pullin, A.S. 2008. The relative importance of grazing stock type and grazing intensity for conservation of mesotrophic 'old meadow’ pasture. J. Nat. Conserv. 16: 175-185.

Sutherland, W.J., Pullin, A.S., Dolman, P.M. and Knight, T.M. 2004. The need for evidence-based conservation. - Trends Ecol. Evol. 19: 305-308.

Swedish Board of Agriculture 2015. Utbetalning av miljöersättning för betesmarker och slåtterängar.

$<$ http://www.jordbruksverket.se/amnesomraden/stod/jordbrukarstod/miljo ersattningar/nyaersattningar/betesmarkerochslatterangar/utbetalning.4.4c 6781514b9df8f29ed873c.html>, accessed 24 August 2015. In Swedish.

Swedish Environmental Protection Agency. 2011. Natura 2000. < http://www.naturvardsverket.se/Miljoarbete-i-samhallet/Miljoarbete-iSverige/Uppdelat-efter-omrade/Naturvard/Skydd-av-natur/Natura2000/>, accessed 31 August 2015. In Swedish.

The IUCN Red List of Threatened Species. Version 2014.3. <www.iucnredlist.org>, accessed 10 March 2015. 
Tälle, M., Bergman, K.-O., Paltto, H., Pihlgren, A., Svensson, R., Westerberg, L., Wissman, J. and Milberg, P. 2014. Mowing for biodiversity: grass trimmer and knife mower perform equally well. Biodivers. Conserv. 23: 3073-3089.

Török, P., Valkó, O., Deák, B., Kelemen, A., and Tóthmérész, B. 2014. Traditional cattle grazing in a mosaic alkali landscape: effects on grassland biodiversity along a moisture gradient. - PloS ONE 9: e97095.

Török, P., Vida, E., Deák, M., Lengyel, S. and Tóthmérész, B. 2011. Grassland restoration on former croplands in Europe: an assessment of applicability of techniques and costs. - Biodivers. Conserv. 20: 23112332.

Valkó, O., Török, P., Matus, G. and Tóthmérész, B. 2012. Is regular mowing the most appropriate and cost-effective management maintaining diversity and biomass of target forbs in mountain hay meadows? - Flora 207: 303-309.

Wahlman, H. and Milberg, P. 2002. Management of semi-natural grassland vegetation; evaluation of long-term experiment in southern Sweden. - Ann. Bot. Fenn. 39: 159-166.

Wilson, J.B., Peet, R.K., Dengler, J. and Pärtel, M. 2012. Plant species richness: the world records. - J. Veg. Sci. 23: 796-802. 
Zhao, W.Y., Li, J.L. and Qi, J.G. 2007. Changes in diversity and structure in response to heavy grazing pressure in Northern Tianshan Mountains, China. - J. Arid. Environ. 68: 465-479. 
1 Table 1. Description and years of inventory for the experimental sites

2 established in southern Sweden for the comparison of management

3 methods in semi-natural grassland vegetation.

\begin{tabular}{|c|c|c|c|c|c|c|c|}
\hline \multirow[t]{2}{*}{ Site } & \multicolumn{2}{|l|}{$\begin{array}{l}\text { Year of } \\
\text { inventory }\end{array}$} & $\begin{array}{l}\text { Vegetation } \\
\text { type }\end{array}$ & $\begin{array}{l}\text { Soil } \\
\text { category }\end{array}$ & $\begin{array}{l}\text { Management } \\
\text { at start of trial }\end{array}$ & $\begin{array}{l}\text { Grazing } \\
\text { animal }\end{array}$ & $\begin{array}{l}\text { Grazing } \\
\text { intensity }\end{array}$ \\
\hline & 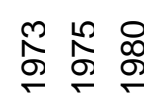 & $\begin{array}{ll}\stackrel{0}{0} & \hat{\infty} \\
\stackrel{\circ}{\sim} & \stackrel{\sim}{\sigma}\end{array}$ & & & & & \\
\hline $\begin{array}{l}\text { Andersby, } \\
\text { Dannemora }\end{array}$ & $x$ & $x$ & Moist meadow & $\begin{array}{l}\text { Humus- } \\
\text { rich light } \\
\text { clay }\end{array}$ & Grazing & Cattle & Low \\
\hline $\begin{array}{l}\text { Bråbo, } \\
\text { Oskarshamn }\end{array}$ & $x$ & $x$ & Mesic meadow & $\begin{array}{l}\text { Rock } \\
\text { moraine }\end{array}$ & Grazing & Cattle & Normal \\
\hline $\begin{array}{l}\text { Bräcke, } \\
\text { Åmål }\end{array}$ & $x \quad x$ & $x$ & Mesic meadow & Silt & Grazing & Cattle & Low \\
\hline $\begin{array}{l}\text { Dämkärr, } \\
\text { Gamleby }\end{array}$ & $x$ & $x$ & Mesic meadow & $\begin{array}{l}\text { Humus- } \\
\text { rich silt }\end{array}$ & Abandoned & $\begin{array}{l}\text { Cattle, } \\
\text { sheep, } \\
\text { horses }\end{array}$ & Low \\
\hline Ekenäs, Flen & & & & & & & \\
\hline Moist & $x$ & $x$ & Moist meadow & $\begin{array}{l}\text { Highly } \\
\text { humus- } \\
\text { rich light } \\
\text { clay }\end{array}$ & Grazing & Cattle & Normal \\
\hline Mesic & $x \quad x$ & $x$ & $\begin{array}{l}\text { Dry-mesic } \\
\text { meadow }\end{array}$ & $\begin{array}{l}\text { Humus- } \\
\text { rich } \\
\text { loamy }\end{array}$ & Grazing & Cattle & Normal \\
\hline
\end{tabular}




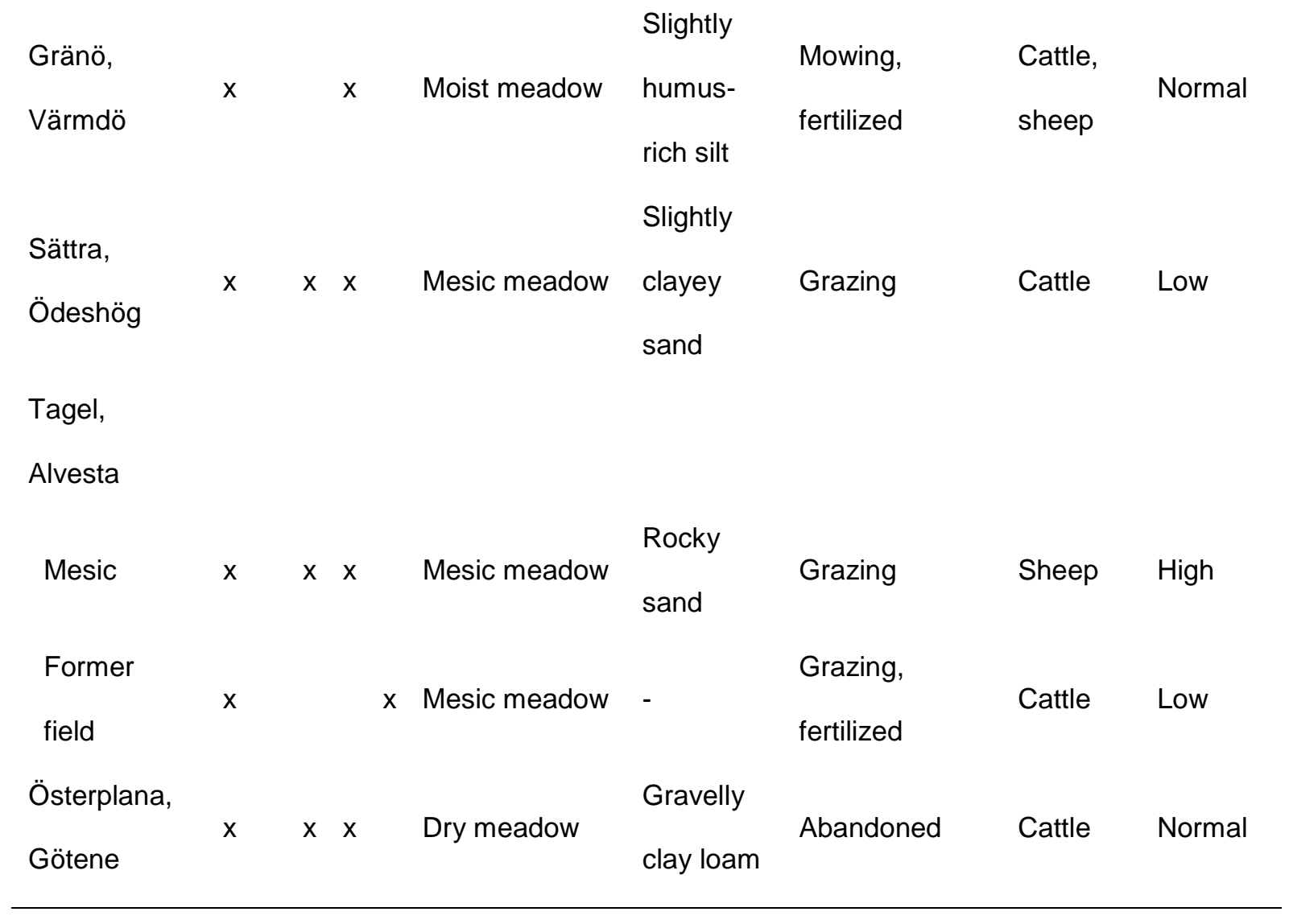


Table 2. Meadow types present in the study sites, description and examples of characteristic species.

\begin{tabular}{|c|c|c|}
\hline $\begin{array}{l}\text { Meadow } \\
\text { type }\end{array}$ & Description† & $\begin{array}{l}\text { Examples of characteristic } \\
\text { species }{ }^{\dagger}\end{array}$ \\
\hline Dry & $\begin{array}{l}\text { Well-drained or dry semi- } \\
\text { natural grasslands } \\
\text { dominated by grasses or } \\
\text { herbs, mostly with low } \\
\text { productivity (EUNIS habitat } \\
\text { classification: E1) }\end{array}$ & $\begin{array}{l}\text { Bromus hordeaceus, } \\
\text { Campanula rotundifolia, } \\
\text { Cerastium semidecandrum, } \\
\text { Festuca ovina, } \\
\text { Helianthemum nummularium, } \\
\text { Myosotis stricta, Pimpinella } \\
\text { saxifraga, Trifolium } \\
\text { montanum, Veronica verna }\end{array}$ \\
\hline Mesic & $\begin{array}{l}\text { Lowland mesotrophic and } \\
\text { eutrophic semi-natural } \\
\text { grasslands, generally more } \\
\text { productive than dry } \\
\text { grasslands (EUNIS habitat } \\
\text { classification: E2) }\end{array}$ & $\begin{array}{l}\text { Arnica montana, Briza } \\
\text { media, Leontodon hispidus, } \\
\text { Leucanthemum vulgare, } \\
\text { Platanthera bifolia, Polygala } \\
\text { vulgaris, Primula veris, } \\
\text { Scorzonera humilis, Veronica } \\
\text { chamaedrys }\end{array}$ \\
\hline Wet & $\begin{array}{l}\text { Wet semi-natural grasslands, } \\
\text { containing tall herb } \\
\text { communities, more } \\
\text { productive than dry and } \\
\text { mesic grasslands (EUNIS } \\
\text { habitat classification: E3) }\end{array}$ & $\begin{array}{l}\text { Carex cespitosa, Galium } \\
\text { uliginosum, Juncus spp., } \\
\text { Potentilla anserina, Succisa } \\
\text { pratensis }\end{array}$ \\
\hline
\end{tabular}

†Information from Davies et al. 2004.

††Information from Ekstam \& Forshed 1992. 


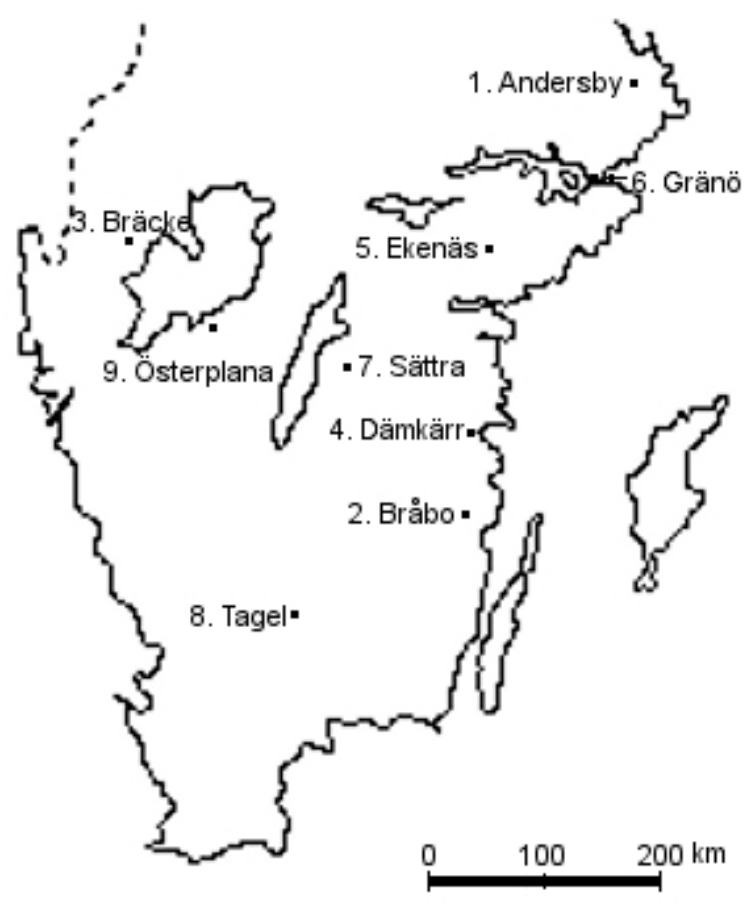

Figure 1. Study locations in southern Sweden. Ekenäs and Tagel had two experimental sites each. 


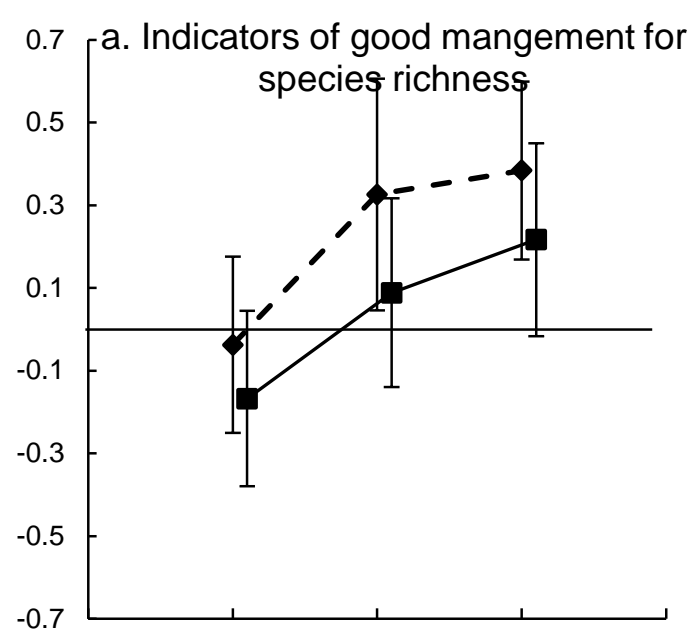

1

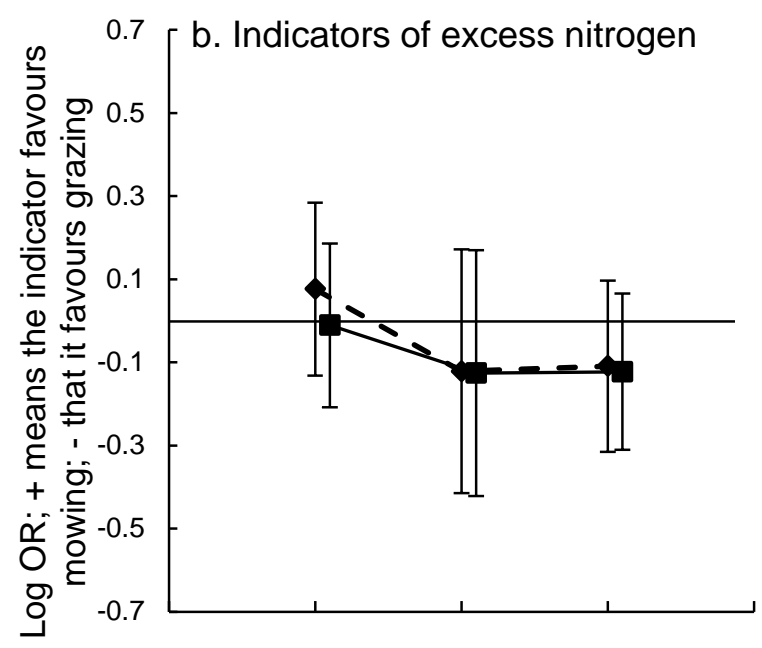

2

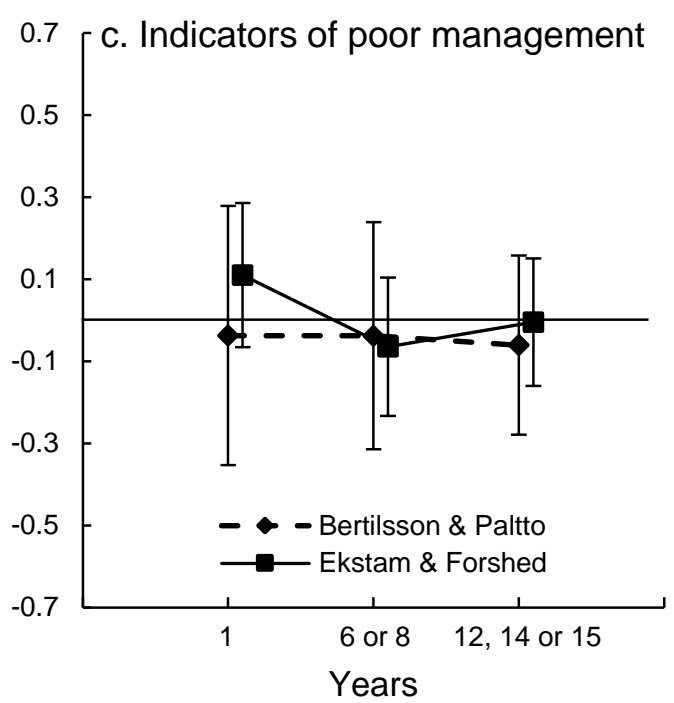


5 Figure 2. Meta-analysis outcomes (Log OR) for the odds of finding

6 indicator vs. non-indicator species in mowed and grazed plots. Data from

$7 \quad 11$ trials in southern Sweden, each containing two independent blocks.

8 Error bars represent 95\% confidence intervals. 


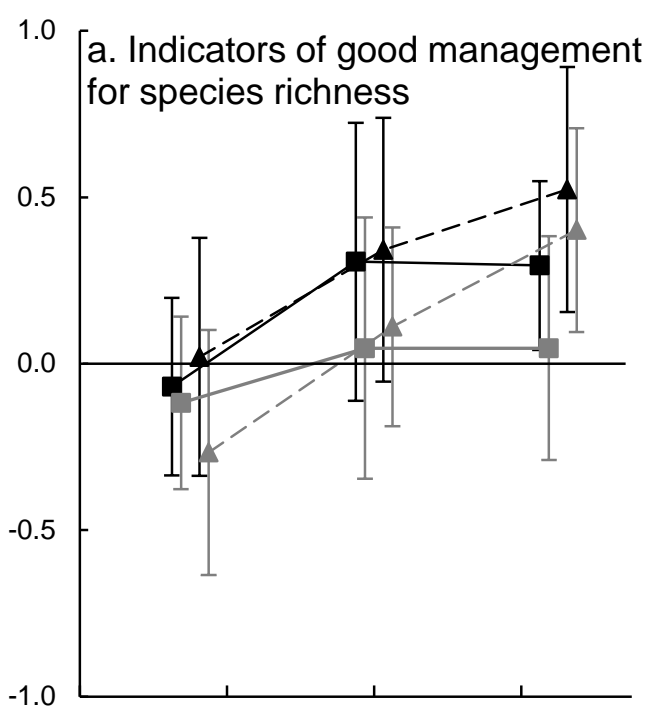

1

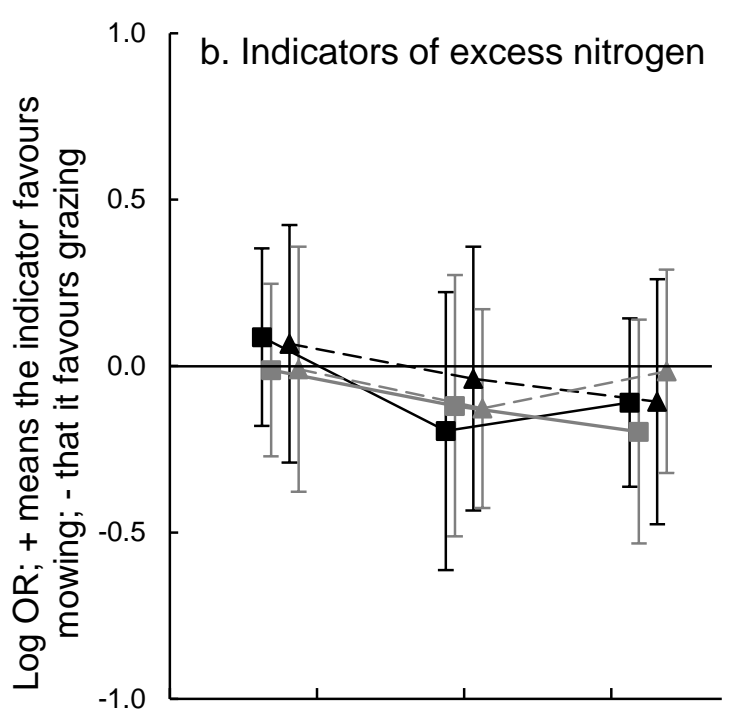

2

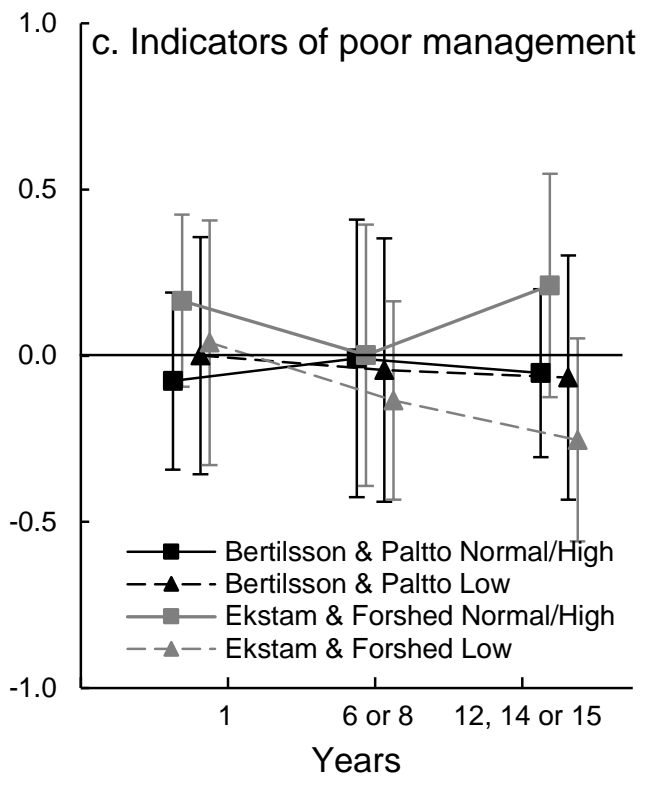


5 Figure 3. Meta-analysis outcomes (Log OR) for the odds of finding indicator vs.

6 non-indicator species in mowed and grazed plots, when grouping trials

7 according to grazing intensity. Data from 11 trials in southern Sweden, each

8 containing two independent blocks. Error bars represent 95\% confidence

9 intervals 